Nyanza Musical Society (Kenya)

Tris society, which was founded in $194 \mathrm{I}$, has two main aims: to encourage the performance and development of the traditional music of Africa and to introduce to those unfamiliar with it, the best music in the Western tradition. The society organizes annual Music Festivals and during recent years a music course has been held for choir-masters entering choirs for the Festival. As a result the standard of performance at the Festivals has greatly improved and also there has been an increasing interest in the serious study of music. At a recent course the experiment was tried of getting choir-masters to write counterpoint in two parts instead of the more ordinary four-part harmony. An African melody, it is thought, is much more likely to retain its original character if another similar melody is added to it in contrapuntal style than if harmonies taken from Western music are used to support it. At the course held in r9s5 an introduction to the study of musical form-both African and European-was given. When a piece of music was analysed, members were interested to discover in it a pattern as well defined as that found, for example, in African basket-work. Moreover it became apparent that the pattern of a Minuet of Mozart was fundamentally the same as that found in miniature in an African folk-song (see African Music, Journal of the African Music Society, vol. i, No. 2, 1955).

\title{
Maps of Africa south of the Sahara
}

C.S.A. publications Nos. I 5 and 17 of 1955 constitute a revision of publication No. 4 of 1953 and embody the recommendations of the Specialist Meeting on maps and geographical surveys convened at Bukavu in 1953 . Publication No. is is devoted to topographical maps, which are listed under territories: scale and a brief description are given for each map as well as information on the agency mainly responsible for mapping each area and territory. Publication No. 17 is concerned with special subject maps, which are classified first under territories and, within each territory, under such headings as Geology, Climate and Hydrology, Soils, Vegetation, Population and Tribal boundaries, Administrative and Political boundaries, Communications.

It is surprising to find no reference, among the maps showing population and tribal boundaries, to the specially drawn maps published with this Institute's Ethnographic Survey of Africa, although the attention of the C.S.A. was drawn to these after the appearance of publication No. 4, in 1953. 